\title{
Mating order-dependent female mate choice in the polygynandrous common lizard Lacerta vivipara
}

\author{
Patrick S. Fitze $\cdot$ Julien Cote $\cdot$ Jean Clobert
}

Received: 29 January 2009/Accepted: 27 August 2009/Published online: 25 September 2009

(C) Springer-Verlag 2009

\begin{abstract}
Recent studies indicate that directional female mate choice and order-dependent female mate choice importantly contribute to non-random mating patterns. In species where females prefer larger sized males, disentangling different hypotheses leading to non-random mating patterns is especially difficult, given that male size usually correlates with behaviours that may lead to non-random mating (e.g. size-dependent emergence from hibernation, male fighting ability). Here we investigate female mate choice and order-dependent female mate choice in the polygynandrous common lizard (Lacerta vivipara). By sequentially presenting males in random order to females, we exclude non-random mating patterns potentially arising due to intra-sexual selection (e.g. male-male competition), trait-dependent encounter probabilities, trait-dependent
\end{abstract}

Communicated by Raoul Van Damme.

P. S. Fitze $(\square)$

Department of Biodiversity and Evolutionary Biology,

Museo Nacional de Ciencias Naturales (MNCN-CSIC),

Calle José Gutiérrez Abascal 2, 28006 Madrid, Spain

e-mail: patrick.fitze@mncn.csic.es

\section{P. S. Fitze}

Instituto Pirenaico de Ecología (IPE-CSIC),

Avenida Regimiento de Galicia s/n, 22700 Jaca, Spain

J. Cote

Laboratoire Fonctionnement et Evolution des Systèmes

Ecologiques, Ecole Normale Supérieure,

46 rue d'Ulm, 75005 Paris, France

J. Clobert

Station d'Ecologie Expérimentale du CNRS à Moulis, USR2936, Moulis, 09200 Saint-Girons, France conspicuousness, or trait-dependent emergence from hibernation. To test for order-dependent female mate choice we investigate whether the previous mating history affects female choice. We show that body size and body condition of the male with which a female mated for the first time were bigger and better, respectively, than the average body size and body condition of the rejected males. There was a negative correlation between body sizes of first and second copulating males. This indicates that female mate choice is dependent on the previous mating history and it shows that the female's choice criteria are non-static, i.e. non-directional. Our study therefore suggests that context-dependent female mate choice may not only arise due to genotypeenvironment interactions, but also due to other female mating strategies, i.e. order-dependent mate choice. Thus context-dependent female mate choice might be more frequent than previously thought.

Keywords Order-dependent mate choice . Context-dependent mate choice - Body size .

Body condition $\cdot$ Lacerta vivipara

\section{Introduction}

Mate choice is an important driving force of sexual selection (Andersson 1994; Darwin 1871). In species where females may gain direct benefits from choosing a given male (e.g. through paternal care, territory defence, access to good territories, nuptial gifts, or protection from predators), males that provide better quality resources are typically preferred (e.g. Andersson 1994; Birkhead and Møller 1998). However, in species where females do not gain direct benefits, it is less obvious why females should be choosy (Jennions and Petrie 2000). 
Several hypotheses may explain why female mate choice for indirect benefits is beneficial and by which processes it may have evolved (Kokko et al. 2003). For example, female mate choice might be exerted to enhance the offspring's genetic quality and thus good-quality males (in genetic terms) should be preferred (Birkhead and Møller 1998; Thornhill and Alcock 1983), or females may maximize the offspring's genetic diversity by favouring genetically dissimilar males (Mays and Hill 2004; Neff and Pitcher 2005; Reusch et al. 2001; Tregenza and Wedell 2000; Zeh and Zeh 1996). However, female mate choice may be restricted and may prevent females from mating with the most preferred male (Jennions and Petrie 2000). As a consequence they may trade-up males by mating with a male to ensure fertilization and thereafter by mating with a male of higher quality (Jennions and Petrie 2000).

Both female mate choice for indirect benefits and trading-up are in line with findings suggesting that optimal female mate choice in those polyandrous species in which females only obtain indirect benefits, may depend on each female's previous mating history (Bakker and Milinski 1991; Pitcher et al. 2003). It may also depend on a female's characteristics (genotype, condition, environment; Alonzo and Sinervo 2001, Hunt et al. 2005; Milinski and Bakker 1992; Richard et al. 2005, Richard et al. 2009) and on mate-searching costs (Milinski and Bakker 1992). This implies that female mate choice may not always be directional and that it may depend on the context in which the choice is exerted (David et al. 2000; Jia et al. 2000; Qvarnström 2001). There is growing evidence that genotype-by-environment interactions exist in sexually selected traits (Danielson-François et al. 2006; David et al. 2000; Jia et al. 2000), and that they may importantly determine female mate choice. This suggests that non-directional female mate choice (not fixed for a single trait) may be the rule rather than the exception (Alonzo and Sinervo 2001). However, the extent to which female mate choice is nondirectional is currently not well understood given that demonstrating non-directional female mate choice is not a simple task. Indeed, observed non-random and non-directional mating patterns can be caused by alternative mechanisms (Bateson 1983; Birkhead and Møller 1998) such as male-male competition for access to females (e.g. Bateson 1983; Cooper and Vitt 1997; Jenssen and Nunez 1998; Tokarz 1998; Olsson 1993; Wong and Candolin 2005), male sexual harassment (Clutton-Brock and Parker 1995; Fitze et al. 2005), trait-dependent differences in behaviour or conspicuousness, or trait-dependent emergence patterns from hibernation (Bateson 1983; Olsson et al. 1996). Consequently, demonstrating that female mate choice is responsible for non-random and non-directional mating patterns requires an experimental approach, which excludes the potential alternative explanations.
Numerous studies have found that females show preferences for certain male characteristics, including preferences for body size, body condition, exaggerated ornaments, and genetic features (e.g. genetic diversity, genetic resistance genes; Andersson 1994; Bateson 1983; Birkhead and Møller 1998; Eberhard 1996; Jennions and Petrie 1997; Kokko et al. 2003; Milinski et al. 2005). Body size has been demonstrated to be one of the most important traits involved in mate choice (Andersson 1994; Bateson 1983). Theoretical models predict that in species with indeterminate growth, females should prefer larger males, given that larger males are longer lived and given that longevity may indicate viability in the current environment (Jennions et al. 2001; Kokko and Mappes 2005; Zahavi 1975). Furthermore, in several species, including reptiles, larger males are more likely to produce fertile sperm (Boretto and Ibargüengoytía 2006; Olsson and Madsen 1998; Santos and Llorente 2001; Van Wyk 1995). Consequently, female preference for larger males may lead to an increased probability of clutch fertilization and to increased offspring viability.

Here we investigate female mate choice and contextdependent female mate choice in the polygynandrous common lizard Lacerta vivipara. Female common lizards usually produce one clutch per year, containing up to 12 eggs (Fitze et al. 2005). Several studies suggest that the common lizard exerts female mate choice (Fitze et al. 2005, 2008; Richard et al. 2005, 2009) and that female mate choice might be constrained by male aggression (Fitze and Le Galliard 2008; Fitze et al. 2005). Female mate choice may also depend on female age, size or genotype (Richard et al. 2005, 2009), suggesting that female mate choice may be non-directional and that it may depend on the social context (Fitze and Le Galliard 2008). Female common lizards do not gain direct benefits from mating (no male mate guarding, no paternal care), but females may obtain indirect benefits (Fitze et al. 2005).

To investigate whether female mate choice is nondirectional we tested whether female mate choice depends on the previous mating history. We designed a staged mating experiment which excluded intra-sexual selection, trait-dependent emergence patterns, trait-dependent differences in conspicuousness, differences in the encounter probabilities between males, and environmental differences, all of them potentially leading to non-random mating patterns (e.g. Cooper and Vitt 1997; Olsson 1993; Olsson et al. 1996). We sequentially presented males in random order to a female and observed the copulation behaviour. Since body size and body condition are known to be important predictors of individual fitness in the common lizard (Fitze et al. 2008; Fitze and Le Galliard 2008; see also Boretto and Ibargüengoytía 2006; Olsson 
and Madsen 1998; Santos and Llorente 2001; Van Wyk 1995 for other lizard species) we concentrated our analyses on these two traits. If female mate choice is directional, we predict that females should consistently mate with larger males (Fitze and Le Galliard 2008), leading to a positive correlation between the first and the second copulating males' traits and to repeatable male characteristics among a female's copulations. If female mate choice is non-directional, we predict that females will not consistently mate with larger males. If female mate choice depends on the previous mating history (context-dependent female mate choice) we predict that the characteristics of the first copulating male may predict those of the second copulating male, but that this association may not be positive, resulting in the latter case to no repeatability of the male's characteristics. We also analysed whether the results may be influenced by male coercion (Fitze et al. 2005). We observed the mating behaviour and we compared the analyses including all copulations with those excluding all coercive copulations. If male coercion importantly influences the mating patterns, we predict that the results of the two types of analyses will differ. Finally, we included a male's previous copulation history into the analyses, to test whether the results may be affected by sperm limitation (Olsson and Madsen 1998).

\section{Materials and methods}

\section{Species description}

The common lizard (Lacerta vivipara) is a small lacertid inhabiting non-exclusive home ranges in peat bogs and moist heath lands (Clobert et al. 1994; Massot et al. 1992). Adult females are larger than adult males, and males emerge from hibernation from February to March, approximately 1 month earlier than females. Copulations happen directly after females emerge from hibernation. In this species, adult males are dominant over 1-year-old males (Lecomte et al. 2004), and fights among males can be observed mainly during the mating season (Heulin 1988; P. S. Fitze, personal observations). Mating lasts from a couple of minutes up to several hours (Heulin 1988). During mating attempts, a male grips the female on the posterior abdomen with its mouth, and then tries to twist his body around hers in order to introduce his hemipenis into the female's cloaca. As a result of the male's grip, the female's belly shows a U-shaped scar (Bauwens and Verheyen 1985). These mating attempts may result immediately in copulation or in combats that may or may not result in copulations. Female common lizards mate with several different males (Heulin 1988). As a consequence, females give birth to offspring which may be fathered by up to five different males (Fitze et al. 2005; Laloi et al. 2004; Richard et al. 2005).

Pre-experimental conditions

All experiments were conducted at the ecological field station of Foljuif (Saint-Pierre-les-Nemours, Seine et Marne, France). Lizards originated from natural populations located on the Mont-Lozère in the Cévennes $(1,500 \mathrm{~m}$ a.s.l., Massif Central, south-eastern France, $44^{\circ} 00^{\prime} \mathrm{N}$, $3^{\circ} 45^{\prime} \mathrm{E}$ ) and were introduced into semi-natural populations located at Foljuif in 1992 for the purpose of other studies (e.g. Lecomte et al. 2004). For the present study, lizards were captured in July 2001 and 2002, and introduced into empty outdoor enclosures $\left(100 \mathrm{~m}^{2}\right)$ which contained natural vegetation, natural food, hides, rocks, and two ponds (for more details see Le Galliard 2003; Lecomte et al. 2004; Lecomte and Clobert 1996). Females and males were released into separate enclosures to prevent uncontrolled mating. In 2001 we established three female and three male enclosures and in 2002 four female and four male enclosures containing on average $( \pm \mathrm{SE}) 44 \pm 3$ lizards. There were no statistical differences in the number of lizards introduced in female or male enclosures $\left(F_{1,12}=1.391\right.$, $P=0.261)$, no significant differences between years $\left(F_{1,11}=3.562, P=0.086\right)$ and the interaction between sex and year was not significant $\left(F_{1,10}=0.001, P=0.982\right)$. To protect the lizards from avian predators the enclosures were covered with nets and to reduce the risk of shrew predation, traps (Ugglan, Grahnab, Sweden) were placed inside and outside the enclosures.

\section{Laboratory conditions}

In early spring 2002 and 2003 the enclosures were regularly inspected to register female emergence. Beside the sex-segregated enclosures, other enclosures containing female and male lizards were regularly inspected, to determine the onset of mating. Mated females were determined by the presence of mating scars, typically being present on the belly of females after copulation (Bauwens and Verheyen 1985). On the day when the first mating scars were detected, adult female [2002, $n=47 ; 2003$, $n=58$; snout-vent length (SVL), $63.979 \pm 0.395 \mathrm{~mm}$, range $55-74 \mathrm{~mm}$; body condition, $0 \pm 0.045$, range -0.915-1.099; see "Statistics"] and adult male lizards (2002, 77; 2003, 165; SVL, $58.397 \pm 0.201 \mathrm{~mm}$, range $48-67 \mathrm{~mm}$; body condition, $0 \pm 0.026$, range -1.111-1.263) were captured in the experimental enclosures. Following capture, lizards were weighed to the nearest $0.002 \mathrm{~g}$. The SVL was measured with 1-mm precision using a transparent ruler. All captured lizards were introduced into individual terraria $(25 \times 15 \times 15 \mathrm{~cm})$ 
layered with soil and equipped with a small water dish and two hides. Terraria were numbered for individual identification of the lizards and the same lizard stayed in the same terrarium during the entire experiment. Terraria were lit with an incandescent bulb ( $25 \mathrm{~W}$ ) from 0900 to 1200 hours and from 1400 to 1700 hours. Lizards were fed moth larvae (Pyralis sp.; $254 \pm 12.64 \mathrm{mg}$ ) every 4 days and water was provided ad libitum (Le Galliard et al. 2003).

\section{Experimental method}

In 2002 the mating experiments lasted from 31 March to 8 April and in 2003 from 7 April to 15 April. The first daily mating experiment started at 0900 hours and the last experiment started no later than 1700 hours. At the start of the experiment a randomly chosen female was introduced into an escape-proof wooden box $\left(2,500 \mathrm{~cm}^{2}\right)$. Each wooden box contained two shelters and a 40-W bulb, which provided light and heat. An additional ultraviolet (UV)-B neon light source provided UV light to mimic the naturally occurring light. Two to 4 min after releasing the females, a randomly selected male was introduced into the female box. Lizards were observed for $1 \mathrm{~h}$. If the lizards were still copulating $1 \mathrm{~h}$ after the initiation of the encounter $5.5 \%$ of the copulations), they were observed until they ended the copulation and $5 \mathrm{~min}$ later the male was removed. Two to 4 min after the male removal a different, randomly chosen male was introduced. We followed this procedure until females copulated with three males. If no successful copulation was observed for 15 subsequent trials we stopped presenting males to the female. When the last daily trial was finished, females were removed from the wooden box and placed back into the terrarium. The following morning they were again introduced into the same wooden boxes. On average males were presented to females for $2.82 \pm 0.17$ days.

The male-presentation frequency was chosen because in a previous observational study, where females and males lived together for several days, males tried to mate with a female on average $1.1 \pm 0.9$ times $\mathrm{h}^{-1}$ (range 0.7-1.8 copulation attempts $\mathrm{h}^{-1}$; Heulin 1988). Since in natural populations $50-68 \%$ of the females give birth to offspring sired by more than one male and since only $4-7 \%$ of the females give birth to offspring sired by more than three different males (Laloi et al. 2004), females were allowed to copulate with no more than three different males. On average the mating experiments started $3.36 \pm 0.23$ days after capture. Statistical analyses revealed that the female presentation order (number of days a female stayed in the laboratory before the mating experiments) was random with respect to female SVL $\left(r=0.099, F_{1,94}=0.947\right.$, $P=0.333)$, body mass $\left(r=-0.092, \quad F_{1,94}=0.808\right.$, $P=0.371)$, and the time a female lasted until she copulated for the first time (Spearman $\rho=0.176, n=96$, $P=0.105)$. This indicates that the experimental protocol did not affect female behaviour and that it cannot explain non-random patterns.

Males were randomly presented to females from the start of the experiment until the first copulation [analysis of covariance (ANCOVA) with SVL as dependent variable, female and year as random effects, and male order as covariate: $F_{1,356}=1.73, P=0.19$ ], from the first until the second copulation $\left(F_{1,205}=0.739, P=0.39\right)$, and from the second until the third copulation $\left(F_{1,152}=0.079\right.$, $P=0.78)$. Furthermore, there was no difference in SVL of the males presented to a female until her first copulation and from her first copulation until her second copulation (repeated measures ANOVA with mean SVL of the males presented to a female until her first copulation and mean male SVL of the males presented from the female's first until her second copulation as repeated measures: $F_{1,73}=0.756, P=0.387$ ). To avoid potential influences of a male's previous mating history, males were presented to females every $1.33 \pm 0.05$ days and they were allowed to copulate with a maximum of three different females.

To investigate whether male coercion exists and to distinguish between female mate choice and forced copulation we observed the mating behaviour in 2002. We quantified whether a female allowed a male to grip her abdomen and to copulate, or whether she tried to resist. Females that tried to resist usually fended off a male's grip, by trying to escape, or by biting the male. Both behaviours usually resulted in combats between the female and the male. To determine the frequency of forced copulation we observed whether combats between mates resulted in copulation, or whether a female was able to resist and thus to exert her mate preference.

A female-male encounter was defined as 'copulation' when the male gripped the female with the mouth on the posterior abdomen, successfully twisted his body around the female, and inserted his hemipenis into the cloacae. After the copulations took place, lizards were inspected for injuries caused by the inter-sexual interactions. No serious injuries (e.g. bleeding or loss of scales) could be found on females or males. However, mating scars, which typically arise due to the biting (Bauwens and Verheyen 1985), were visible on all mating females. At the end of the experiment, male and female lizards were released into their separate outdoor enclosures.

\section{Statistics}

For modelling mating probabilities we used Proc GLIMMIX in SAS using a binomial error distribution and a logit link (Littell et al. 1996). To check for differences between years, we included year as a random factor in all analyses 
and explored the interaction effect of year with the covariates. Non-significant interactions $(P>0.05)$ were backward eliminated. Body condition was modelled by adding both body mass and SVL to the statistical model (Darlington and Smulders 2001; García-Berthou 2001). For the analyses of body condition using Spearman rank correlations and Wilcoxon signed-rank tests we used the residuals of the regression with SVL as the independent variable and body mass as the dependent variable. In several analyses dealing with the male's body mass the $d f$ were reduced because measurements for four males were missing.

The assumptions of the statistical models were verified in all cases (e.g. for ANOVAs: homoscedasticity and normality of the error; Quinn and Keough 2002). For the correlation between number of males presented to a female until the first copulation and the similarity of the SVL of the two partners, both the dependent and the independent variable were log transformed to meet the assumptions of the tests. For some models, the assumptions were not met after transformation. Consequently, we applied Spearman rank order correlations, instead of parametric regression analyses, or Wilcoxon signed-ranks test for the analysis of paired samples (Siegel and Castellan 1988). To understand whether the results of the ANCOVA with SVL of the second copulating male as dependent variable and SVL of the first copulating male as covariate and year as a random factor arose due to female preferences or due to the experimental design, we confirmed the results using resampling methods based on 10,000 random permutations (Manly 2001). The repeatability $(r)$ of the mate partner's traits was calculated according to Lessells and Boag (1987). Significance levels of all reported tests are twotailed with a 0.05 significance level. Means $\pm 1 \mathrm{SE}$ are given.

\section{Results}

Female behaviour prior to copulation

To understand whether non-random mating patterns may arise due to female mate choice or due to male coercion, we observed the mating behaviour prior to copulation in 2002. Of 223 observed encounters, 90 resulted in successful copulation. In 53 of the 90 copulations the males gripped the females on the posterior abdomen and immediately started to copulate. In 48 of the 223 encounters males tried to copulate by gripping females on the posterior abdomen for several minutes (Table 1$)$. An average $( \pm \mathrm{SE})$ of $16 \pm 3 \mathrm{~min}$ (range $0-60 \mathrm{~min}$ ) passed between the release of the males and the initiation of the grip. In $77.1 \%$ $(n=37$; Table 1$)$ of the cases copulation was observed $9 \pm 2 \mathrm{~min}$ (range 2-50 min) after the initiation of the grip, while in $22.9 \%$ no copulation resulted. We tested in males that were biting females whether male copulation success depends on the male phenotype, but could not find any significant differences in SVL $\left(F_{1,46}=1.107, P=0.298\right.$, $n=48)$ or body condition $\left(F_{1,46}=3.347, P=0.074\right)$ between males that subsequently did or did not copulate. Similarly, we could not find significant differences between males that immediately started to copulate $(n=53)$ and males ( $n=37$; Table 1 ) that copulated several minutes after the initiation of the grip (SVL, $F_{1,88}=0.228$, $P=0.634$; body condition, $\left.F_{1,88}=0.351, P=0.555\right)$. In seven cases $(3.1 \%$ of the 223 encounters or $6.9 \%$ of the 101 encounters where the male gripped the female) females tried to fend the males off by biting the gripping mate. In three of the seven encounters (Table 1) where females were biting the male, males successfully coerced females after an intense combat. In the other four encounters no copulation followed. The probability of copulation was

Table 1 Female behaviour during mating attempts

\begin{tabular}{|c|c|c|c|c|c|c|}
\hline \multirow[t]{2}{*}{ Female behaviour } & \multicolumn{3}{|c|}{$\begin{array}{l}\text { Encounters where the male's grip did } \\
\text { not result into immediate copulation }\end{array}$} & \multicolumn{3}{|c|}{ Copulation sequence } \\
\hline & $\begin{array}{l}\text { Copulation follows } \\
\text { after several } \\
\text { minutes }\end{array}$ & $\begin{array}{l}\text { No copulation } \\
\text { follows }\end{array}$ & $\begin{array}{l}\text { Total number } \\
\text { encounters } \\
\text { (n) per category }\end{array}$ & $\begin{array}{l}\text { 1st } \\
\text { copulation }\end{array}$ & $\begin{array}{l}\text { 2nd } \\
\text { copulation }\end{array}$ & $\begin{array}{l}\text { Total number } \\
\text { of copulations } \\
\text { (n) per category }\end{array}$ \\
\hline No female defence & 34 & 7 & 41 & & & \\
\hline Female bites gripping male & 3 & 4 & 7 & & & \\
\hline Total number encounters $(n)$ per category & 37 & 11 & 48 & & & \\
\hline Copulated with first presented male & & & & 35 & 25 & 60 \\
\hline Rejected at least one male & & & & 61 & 48 & 109 \\
\hline Total number copulations $(n)$ per category & & & & 96 & 73 & 169 \\
\hline
\end{tabular}

Shown are the number of times a female behaviour was recorded. Fifty-three of the 223 experimental encounters conducted in 2002 resulted in immediate copulation, while in 48 encounters no immediate copulation followed. A total of 105 females were used for the mating experiments in 2002 and 2003. Nine females never copulated, 96 were observed at the first and 73 at the second copulation 
significantly smaller if the female bit the male (43 vs. $83 \%$; Fisher's exact test, $P=0.039$; Table 1). Forced mating may thus have happened in $3.33 \%$ of the 90 copulations. For these seven males, neither SVL nor body condition were different between copulating males (55.67 \pm $2.12 \mathrm{~mm})$ and non-copulating males $(57.75 \pm 1.84 \mathrm{~mm}$; SVL, $F_{1,5}=0.552, P=0.491$; body condition, $F_{1,5}=$ $0.004, P=0.953)$. There were also no differences in SVL $(z=-1.440, P=0.150)$ or body condition $\left(F_{1,5}=0.032\right.$, $P=0.865)$ of forced and not forced females. To check whether coercion may be responsible for the results presented below, we ran all presented analyses excluding the three coercive copulations. Because the results only marginally changed and none of the tests switched from significant to non-significant or vice versa, we do not present these additional analyses.

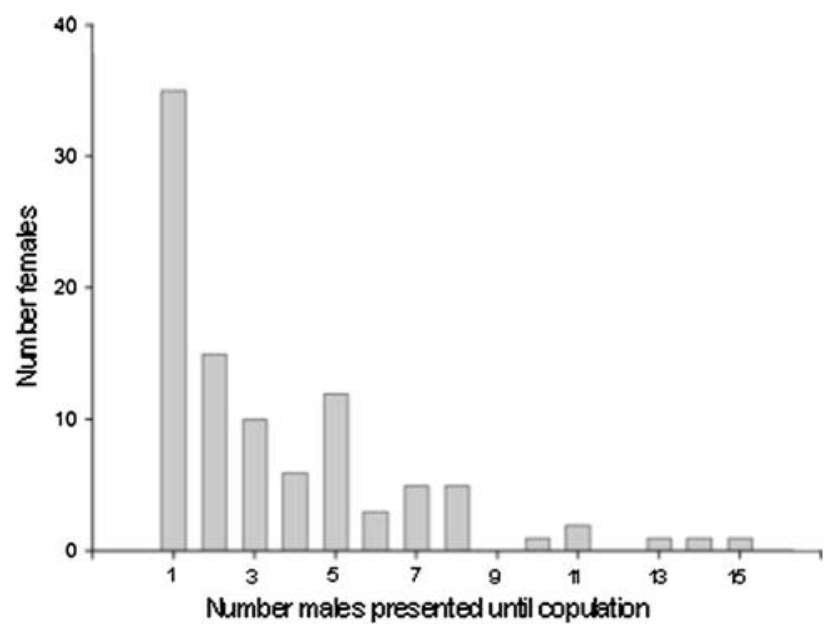

Fig. 1 Distribution of the number of males a female encountered until she copulated for the first time
First copulation

In total, nine of the 105 females used in the staged mating experiments $(8.6 \%)$ failed to copulate, even though we presented them with at least 15 different males (two of 47 females in 2002 and seven of 58 females in 2003). Females in good body condition were more likely to copulate (Proc GLIMMIX: $\quad F_{1,102}=4.60, \quad P=0.034, \quad$ logit $\quad$ slope $3.110 \pm 1.450 \mathrm{SE}$ ) and there was no significant association between the probability of copulating with at least one male and the female's SVL $\left(F_{1,102}=2.79, P=0.098\right.$, logit slope $-0.525 \pm 0.314 \mathrm{SE})$ or the year $(z<0.01$; $P=1$; all interactions with year $P>0.2$ ).

Ninety-six females copulated with at least one male (Table 1). We had to present them $4.5 \pm 0.3$ males until they copulated for the first time (Fig. 1). Figure 1 shows that 35 females (36.5\%) mated with the first presented male (see also Table 1). There was a negative association between the number of potential mates presented to a female and the female's SVL (1.9\% of total variance explained; Table 2; Fig. 2a). There were no differences between years and the potential mate's mating history was not significant. There was also a significant and negative association between the number of potential mates presented and the female's body condition (Table 2). No significant association was present between the number of potential mates presented to a female and the copulating male's SVL $\left(F_{1,93}=0.800 ; P=0.373\right.$; Fig. $\left.2 \mathrm{~b}\right)$ or body condition $\left(F_{1,89}=0.603 ; P=0.440\right)$.

To investigate whether females show preferences for larger males at the first copulation, we analysed the mating behaviour of females that rejected at least one male $(n=61$; Table 1). In these females the SVL difference and the body condition difference between the mates was smaller than the average difference between the female and the rejected mates, i.e. the males that did not copulate

Table 2 Association between the numbers of males presented to a female until copulation and the female's traits at the first copulation

\begin{tabular}{|c|c|c|c|c|c|}
\hline Trait & Parameter & $d f$ & $F$ & Significance & Estimate $\pm \mathrm{SE}$ \\
\hline \multirow[t]{4}{*}{ SVL } & Number of males & 1,93 & 8.660 & $* *$ & $-0.393 \pm 0.134$ \\
\hline & Year & 1,93 & 5.212 & & \\
\hline & Interaction & 1,92 & 0.072 & & \\
\hline & Percent of presented males that copulated previously & 1,91 & 0.341 & & \\
\hline \multirow[t]{5}{*}{ Body condition } & Number of males & 1,92 & 4.678 & $*$ & $-0.034 \pm 0.016$ \\
\hline & Year & 1,92 & 0.586 & & \\
\hline & Interaction & 1,90 & 0.105 & & \\
\hline & Percent of presented males that copulated previously & 1,91 & 0.208 & & \\
\hline & SVL & 1,92 & 129.957 & $* *$ & \\
\hline
\end{tabular}

Analysis of covariance (ANCOVA) with year as a random factor and number of presented males and \% of presented males that copulated previously as covariates

SVL Snout-vent length

** $P<0.01, * P<0.05$ (after sequential Bonferroni correction) 



Fig. 2 Female choosiness. a Regression of the number of males a female faced until the first successful copulation and the female's body size [snout-vent length $(S V L) ; \quad P<0.01$, estimate $-0.393 \pm$ $0.134 \mathrm{SE}$; for further details see Table 2]. b Regression of the number of males a female faced until the first successful copulation and the mate's body size (SVL; $P=0.37$ ). The size of the dots refers to the number of observations (smallest dots $n=1$, biggest dots $\mathbf{a} n=8, \mathbf{b}$ $n=7$ ). The least squares regression line is plotted

(Table 3). Additionally, copulating males were larger and showed better body condition than males that did not copulate (Table 3).

\section{Second copulation}

After the first copulation, 73 females copulated with a second male (Table 1). Thirty-four percent copulated with the first presented male. On average $3.3 \pm 0.3$ males had to be presented to a female between her first and the second copulation (maximum 11th, 90\% quantile 7 th male). The copulation interval was on average $24.1 \mathrm{~h} \pm 3.2 \mathrm{SE}$ (range 20 min-4.3 days). At the second copulation females rejected more males than at the first copulation (Wilcoxon signed-ranks: $z=2.966, P=0.003$, mean number males at first copulation $=3.1 \pm 0.3$ ). The average SVL difference between the potential mates of females that rejected at least one potential mate was not significantly different between copulating and not copulating pairs (Table 3) and the average male SVL was not significantly different between copulating and non-copulating males. The body condition difference of copulating pairs was smaller than that of non-copulating pairs (Table 3 ) and copulating males were in significantly better body condition than non-copulating males.

Repeatability of a female's mate partner characteristics

\section{First versus second copulation}

The percentage of females that immediately copulated with the first presented male was not different at the first and at the second copulation $\left(\chi^{2}=0.018, P=0.892\right)$.

To investigate whether females consider her previous mating history when deciding with whom to mate, we analysed the characteristics of the copulating males at the female's first and second copulations. There were no significant differences between first and second copulating males in terms of SVL (repeated measures ANOVA: $\left.F_{1,73}=0.058, P=0.810\right)$ and body condition $\left(F_{1,71}=\right.$ $1.771, P=0.188)$. The SVL of the second copulating male was negatively associated with the SVL of the first copulating male (Table 4; Fig. 3). We ran a random permutation test to understand whether the negative correlation arose due to female mate choice (the observed negative correlation would be significantly different from the expected correlations) or due to the experimental design (the observed negative correlation would not be different from the expected correlations). The observed correlation was significantly different from the expected correlations ( $n=10,000$ permutations, $P=0.003$ ). There were no significant differences between years and the interaction between year and the first copulating male's SVL was not significant (Table 4). There was no significant association between the body condition of the second and the first copulating male (Table 4).

\section{All copulations}

To test whether female mate choice is directional, we also investigated whether the mate's traits were repeatable among copulations. Male SVL and body condition were not repeatable among copulations $\left(\mathrm{SVL}, F_{72,121}=0.739\right.$, $P=0.919$, repeatability $(r)=-0.109$; body condition, $\left.F_{71,118}=1.092, P=0.332, \quad r=0.034\right)$. However, the number of potential mates that had to be presented to a female until the first, between the first and second, and between the second and third copulation was repeatable 
Table 3 Differences in average partner trait differences (female trait - mean male trait) and differences in average male traits between encounters resulting and not resulting in copulation at the first and at the second copulation

\begin{tabular}{|c|c|c|c|c|c|c|c|c|c|c|}
\hline & \multicolumn{10}{|l|}{ Mean \pm SE } \\
\hline & \multicolumn{5}{|l|}{ First copulation } & \multicolumn{5}{|c|}{ Second copulation } \\
\hline & Copulating & $\begin{array}{l}\text { Not } \\
\text { copulating }\end{array}$ & $n$ & $z$ & $\begin{array}{l}\text { Significance } \\
\text { after correction }\end{array}$ & Copulating & $\begin{array}{l}\text { Not } \\
\text { copulating }\end{array}$ & $n$ & $z$ & $\begin{array}{l}\text { Significance after } \\
\text { correction }\end{array}$ \\
\hline \multicolumn{11}{|c|}{ Partner trait differences } \\
\hline$\Delta \mathrm{SVL}(\mathrm{mm})$ & $4.79 \pm 0.57$ & $6.26 \pm 0.56$ & 54 & 3.603 & $* * *$ & $5.21 \pm 0.64$ & $6.30 \pm 0.49$ & 47 & 1.932 & \\
\hline$\Delta$ Body condition & $-0.14 \pm 0.07$ & $0.06 \pm 0.06$ & 55 & 4.748 & $* * *$ & $-0.23 \pm 0.09$ & $0.05 \pm 0.08$ & 47 & 3.175 & $* *$ \\
\hline \multicolumn{11}{|l|}{ Male traits } \\
\hline SVL (mm) & $59.12 \pm 0.35$ & $57.64 \pm 0.28$ & 53 & 3.564 & $* * *$ & $59.33 \pm 0.41$ & $58.25 \pm 0.31$ & 47 & 1.910 & \\
\hline Body condition & $0.08 \pm 0.04$ & $-0.10 \pm 0.04$ & 58 & 3.511 & $* * *$ & $0.16 \pm 0.06$ & $-0.13 \pm 0.05$ & 47 & 3.837 & $* * *$ \\
\hline
\end{tabular}

Wilcoxon signed-rank tests for paired samples are presented. Mean and SEs are given for encounters with and without copulation $* * * P<0.001, * * P<0.01$ (after Bonferroni correction)

Table 4 Association between the first and the second copulating male's traits

\begin{tabular}{|c|c|c|c|c|c|}
\hline Trait & Parameter & $d f$ & $F$ & Significance & Estimate $\pm \mathrm{SE}$ \\
\hline \multirow[t]{3}{*}{ SVL } & SVL first male & 1,70 & 6.300 & $*$ & $-0.283 \pm 0.129$ \\
\hline & Year & 1,70 & 4.263 & & \\
\hline & Interaction & 1,69 & $<0.001$ & & \\
\hline \multirow[t]{3}{*}{ Body condition } & Body condition first male & 1,69 & 1.325 & & \\
\hline & Year & 1,69 & $<0.001$ & & \\
\hline & Interaction & 1,67 & 0.422 & & \\
\hline
\end{tabular}

ANCOVA results with the second copulating male's traits as dependent variable, year as a random factor and the first copulating male's traits as covariates

$* P<0.05$ (after Bonferroni correction)

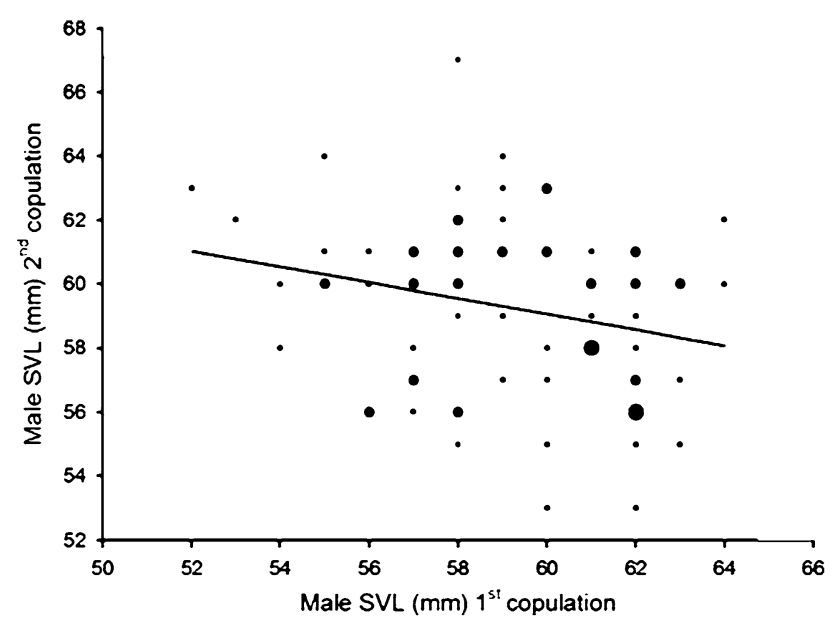

Fig. 3 Association between the accepted male's SVL at the first and second copulation $(P<0.05$, estimate $-0.283 \pm 0.129 \mathrm{SE}$; for further details see Table 4). Dot size corresponds to the sample size (smallest dot $n=1$, largest dot $n=3$ ). The least squares regression line is plotted

$\left(F_{72,121}=1.548, \quad P=0.017, \quad r=0.171\right) . \quad$ In contrast, the number of females that had to be presented to a male until he copulated was not repeatable $\left(F_{51,56}=0.875\right.$,
$P=0.684, r=-0.064)$ and there was no association between the number of females that had to be presented to a male until he copulated and his body size or body condition (ANCOVA: SVL, $F_{1,118}<0.001, P=0.992$; body condition, $\left.F_{1,114}=0.911, P=0.342\right)$.

\section{Discussion}

Our results show that female common lizards preferentially mate with males in better body condition and, at the first copulation, with larger males. Intra-sexual selection, nonrandom emergence patterns, and differences in conspicuousness and encounter probabilities can be ruled out due to the experimental design, and no evidence for male mate choice was found (neither in the behaviour previous to copulation, nor in the repeatability measures). The results therefore indicate that female mate choice led to the observed patterns. We also show that female mate choice depends on the previous mating history being in line with order-dependent female mate choice and more broadly with context-dependent female mate choice. 


\section{Matting patterns}

We found that the number of potential mates presented to a female until copulation was repeatable and in males no repeatability was observed. Not all males that attempted to mate were able to copulate, partly because females resisted the copulation attempts by fending off the males. The success of fending off was not dependent on the male's characteristics. These results show that to some degree female common lizards have the control over mating. Our results also suggest that males can force females to copulate since $3.3 \%$ of the observed copulations occurred after intense combats. However, its rarity, and the fact that the results did not change when the forced copulations were excluded from the analyses, indicate that in this study coercion may have played a minor role. Together with an earlier study (Fitze et al. 2005) this result indicates that coercion might be rare or dependent on specific circumstances (e.g. high male densities; Fitze et al. 2005).

As predicted from earlier studies (Fitze et al. 2005) females did not mate with each male and they preferentially mated with larger males at the first copulation and with males of better body condition at the first and the second copulation. Our results also indicate that female mate choice depends on female body size and body condition because the number of males that had to be presented to a female before copulation was negatively associated with her body size and body condition and no such correlation existed for males. Given that we used only adult females for our study, the negative association indicates that smaller females and thus intermediate-aged females might have been choosier. This result is in line with the study of Richard et al. (2005) which suggested that older and larger females were less choosy than intermediate-aged and intermediate-sized females. The observed results cannot be explained by male control or male mate choice, because we found no repeatable male mating preferences, and because a male's previous copulation history and a male's readiness to mate (probability that a male copulated on a given day in relation to his body size, logistic regression: SVL, $n=97, \chi^{2}=1.058, P=0.304$ ) did not significantly affect the mating pattern. These results are in line with three other studies on lizards, showing that at the first copulation females prefer, on average, larger males (Censky 1997; Cooper and Vitt 1993; Richard et al. 2005). However, our study does not allow us to conclude whether females prefer similar-sized males or larger males, because the statistics investigating preference for similar sized males or larger males showed similar results.

There are at least two potential explanations for why females should, on average, select males of larger body size. First, theoretical models predict that females should prefer long-lived males because longevity may indicate viability in the current environment (Jennions et al. 2001; Kokko and Mappes 2005; Zahavi 1975). This hypothesis would predict that common lizard females should prefer larger males, because they are older. However, Richard et al. (2005) found that high performing males (males with high fitness) were intermediate aged, and young and old males performed worst, clearly contrasting with this hypothesis. Second, larger males are more likely to produce fertile sperm than small males (Boretto and Ibargüengoytía 2006; Olsson and Madsen 1998; Santos and Llorente 2001; Van Wyk 1995). Females may thus prefer larger males at the first copulation to increase the probability of obtaining viable sperm, suggesting that they may hedge against unfertile sperm. This hypothesis is in line with a previous study (Fitze et al. 2005) that found that the number of laid eggs and the number of viable offspring increased with the degree of polyandry independently of female body size, suggesting that females benefit from copulation with multiple males. Both strategies, copulation with multiple males and copulation with larger males at the first copulation may thus have evolved to increase a female's reproductive success.

\section{Order-dependent mate choice}

Our results show that different females show different levels of choosiness given that the number of males that had to be presented to a female was repeatable. But, female mate choice was not constant in time, because mate characteristics were not repeatable among copulations and because of the negative association between the first and second mate's body size. The latter indicates that a female's mate choice depends on her previous mating history and that females may trade-up by first mating to ensure fertilization of the eggs, and by subsequently mating with males of higher quality (e.g. greater body condition; Jennions and Petrie 2000). This finding is consistent with context-dependent female choice (Alonzo and Sinervo 2001) and it explains why the mates' traits were not repeatable among copulations. Although body size depends on a male's age, larger males are not always older males. Consequently, choosing the best male seems to be a complex task and a single rule (Foerster et al. 2003), like preference for the largest males, may not be optimal, since the largest males may not always be the best males (Foerster et al. 2003; Richard et al. 2005). Our results also suggest that females may trade-up for male size or that females may increase the diversity of their mates (Jennions and Petrie 2000) both being consistent with female mate choice depending on previous mating history. Thus, our results are in line with recent findings in blue throats (Luscinia svecica), blue tits (Parus caeruleus) and sticklebacks (Gasterosteus aculeatus) where it has been shown 
that female mate preferences are imposing non-directional and non-static selection on males (Foerster et al. 2003; Johnsen et al. 2000; Milinski et al. 2005). Because of the growing evidence that genotype-environment interactions exist in sexually selected traits (Danielson-François et al. 2006; David et al. 2000; Jia et al. 2000), female choice depending on the order and thus on the context, might be the rule rather than the exception (Alonzo and Sinervo 2001), implying that female mate preferences will fluctuate across environments and years (Qvarnström 2001). Genotype-environment interactions would, however, not necessarily predict differences across subsequent mating attempts (Qvarnström 2001). Although in our study females experienced a very similar environment, we found that females preferred males of different body size during the second copulation. Therefore, context-dependent female choice may not only arise due to genotype-environment interactions, but also due to other female mating strategies (for example trading-up or offspring diversification; Jennions and Petrie 2000; Mays and Hill 2004).

In conclusion, our study indicates that female common lizards exert mate preferences and that females may refuse non-preferred males. Female choice was fairly consistent across years, but females mated with different male phenotypes during their first and second copulation. These results are thus consistent with female choice depending on previous mating history and they indicate that females have no consistent and directional preferences for male body sizes among the different mating attempts. Our results thus suggest that context-dependent female choice might be much more widespread than previously thought. Finally, it underscores that selective pressures leading to contextdependent female choice are far from being well understood.

Acknowledgments We thank Pedro Aragón, Gabriele Socri, and Borja Milá for helpful comments, Borja Milá and Paul Bloor for improving the English, and Caroline Naquet for field assistance. The work was performed according to the ABS/ASAB guidelines for ethical treatment of animals and in agreement with the Parc National des Cévennes and the French Ministry of Science and Education. The work was supported by the Spanish Ministry of Education and Science (CGL2005-01187, CGL2008-01522, and Programa Ramón y Cajal to P. S. F.), the French Ministry of Education and Research, the European Research Training Network ModLife (HPRN-CT-200000051), the Federal Office of Education and Science (BBW no. 01.0254 to P. S. F.), and the Swiss National Science Foundation (No. PBBEA-104428 to P. S. F.).

\section{References}

Alonzo SH, Sinervo B (2001) Mate choice games, context-dependent good genes, and genetic cycles in the side-blotched lizard, Uta stansburiana. Behav Ecol Sociobiol 49:176-186

Andersson M (1994) Sexual selection. Princeton University Press, Princeton
Bakker TCM, Milinski M (1991) Sequential female choice and the previous male effect in sticklebacks. Behav Ecol Sociobiol 29:205-210

Bateson P (1983) Mate choice. Cambridge University Press, Cambridge

Bauwens D, Verheyen RF (1985) The timing of reproduction in the lizard Lacerta vivipara differences between individual females. J Herpetol 19:353-364

Birkhead TR, Møller AP (1998) Sperm competition and sexual selection. Academic Press, San Diego

Boretto JM, Ibargüengoytía NR (2006) Asynchronous spermatogenesis and biennial female cycle of the viviparous lizard Phymaturus antofagastensis (Liolaemidae): reproductive responses to high altitudes and temperate climate of Catamarca, Argentina. Amphib-Reptil 27:25-36

Censky EJ (1997) Female mate choice in the non-territorial lizard Ameiva plei (Teiidae). Behav Ecol Sociobiol 40:221-225

Clobert J, Massot M, Lecomte J, Sorci G, De Fraipont M, Barbault R (1994) Determinants of dispersal behavior: the common lizard as a case study. In: Vitt LJ, Pianka ER (eds) Lizard ecology: historical and experimental perspectives. Princeton University Press, Princeton, pp 183-206

Clutton-Brock TH, Parker GA (1995) Sexual coercion in animal societies. Anim Behav 49:1345-1365

Cooper WE Jr, Vitt LJ (1993) Female mate choice of large male broad-headed skinks. Anim Behav 45:683-693

Cooper WE Jr, Vitt LJ (1997) Maximizing male reproductive success in the broad-headed skink (Eumeces laticeps): preliminary evidence for mate guarding, size-assortative pairing, and opportunistic extra-pair mating. Amphib-Reptil 18:59-73

Danielson-François AM, Kelly JK, Greenfield MD (2006) Genotype $\times$ environment interaction for male attractiveness in an acoustic moth: evidence for plasticity and canalization. J Evol Biol 19:532-542

Darlington RB, Smulders TV (2001) Problems with residual analysis. Anim Behav 62:599-602

Darwin C (1871) The descent of man, and selection in relation to sex. Appleton, New York

David P, Bjorksten T, Fowler K, Pomiankowski A (2000) Conditiondependent signalling of genetic variation in stalk-eyes flies. Nature 406:186-188

Eberhard WG (1996) Female control: sexual selection by cryptic female choice. Princeton University Press, Princeton

Fitze PS, Le Galliard J-F (2008) Operational sex ratio, sexual conflict, and the intensity of sexual selection. Ecol Lett 11:432-439

Fitze PS, Le Galliard J-F, Federici P, Richard M, Clobert J (2005) Conflict over multiple partner mating between males and females of polygynandrous common lizards. Evolution 59:2451-2459

Fitze PS, Cote J, Martínez-Rica JP, Clobert J (2008) Determinants of male fitness: disentangling between intra- and inter-sexual selection. J Evol Biol 21:246-255

Foerster K, Delhey K, Johnsen A, Lifjeld JT, Kempenaers B (2003) Females increase offspring heterozygosity and fitness through extra-pair matings. Nature 425:714-717

García-Berthou E (2001) On the misuse of residuals in ecology: testing regression residuals vs. the analysis of covariance. J Anim Ecol 70:708-711

Heulin B (1988) Observations sur l'organisation de la reproduction et sur les comportements sexuels et agonistiques chez Lacerta vivipara. Vie Milieu 38:177-187

Hunt J, Brooks R, Jennions MD (2005) Female mate choice as a condition-dependent life-history trait. Am Nat 166:79-92

Jennions MD, Petrie M (1997) Variation in mate choice and mating preferences: a review of causes and consequences. Biol Rev $72: 283-327$ 
Jennions MD, Petrie M (2000) Why do females mate multiply? A review of the genetic benefits. Biol Rev 75:21-64

Jennions MD, Møller AP, Petrie M (2001) Sexually selected traits and adult survival: a meta-analysis. Q Rev Biol 76:3-36

Jenssen TA, Nunez SC (1998) Spatial and breeding relationships of the lizard, Anolis carolinensis: evidence of intrasexual selection. Behaviour 135:981-1003

Jia FY, Greenfield MD, Collins RD (2000) Genetic variance of sexually selected traits in waxmoths: maintenance by genotype $\times$ environment interaction. Evolution 54:953-967

Johnsen A, Andersen V, Sunding C, Lifjeld JT (2000) Female bluethroats enhance offspring immunocompetence through extra-pair copulations. Nature 406:296-299

Kokko H, Mappes J (2005) Sexual selection when fertilization is not guaranteed. Evolution 59:1876-1885

Kokko H, Brooks R, Jennions MD, Morley J (2003) The evolution of mate choice and mating biases. Proc R Soc Lond B 270:653-664

Laloi D, Richard M, Lecomte J, Massot M, Clobert J (2004) Multiple paternity in clutches of common lizard Lacerta vivipara: data from microsatellite markers. Mol Ecol 13:719-723

Le Galliard J-F (2003) Interactions sociales et dispersion dans des populations structurées dans l'espace. Laboratoire d'écologie. Université Paris VI, Paris

Le Galliard JF, Ferrière R, Clobert J (2003) Mother-offspring interactions affect natal dispersal in a lizard. Proc R Soc Lond B 270:1163-1169

Lecomte J, Clobert J (1996) Dispersal and connectivity in populations of the common lizard Lacerta vivipara: an experimental approach. Acta Oecol 17:585-598

Lecomte J, Boudjemadi K, Sarrazin F, Cally K, Clobert J (2004) Connectivity and homogenisation of population sizes: an experimental approach in Lacerta vivipara. J Anim Ecol 73:179-189

Lessells CM, Boag PT (1987) Unrepeatable repeatabilites: a common mistake. Auk 104:116-121

Littell RC, Milliken GA, Stroup WW, Wolfinger RD (1996) SAS systems for mixed models. SAS Institute, Cary

Manly BFJ (2001) Randomization, bootstrap and Monte Carlo methods in biology. Chapman \& Hall, CRC, Boca Raton

Massot M, Clobert J, Pilorge T, Lecomte J, Barbault R (1992) Density dependence in the common lizard-demographic consequences of a density manipulation. Ecology 73:1742-1756

Mays HL, Hill GE (2004) Choosing mates: good genes versus genes that are a good fit. Trends Ecol Evol 19:554-559

Milinski M, Bakker TCM (1992) Costs influence sequential mate choice in Sticklebacks, Gasterosteus aculeatus. Proc R Soc Lond B 250:229-233

Milinski M, Griffiths S, Wegner KM, Reusch TBH, Haas-Assenbaum A, Boehm T (2005) Mate choice decisions of stickleback females predictably modified by MHC peptide ligands. Proc Natl Acad Sci USA 102:4414-4418
Neff BD, Pitcher TE (2005) Genetic quality and sexual selection: an integrated framework for good genes and compatible genes. Mol Ecol 14:19-38

Olsson M (1993) Male preference for large females and assortative mating for body size in the sand lizard (Lacerta agilis). Behav Ecol Sociobiol 32:337-341

Olsson M, Madsen T (1998) Sexual selection and sperm competition in reptiles. In: Birkhead TR, Møller AP (eds) Sperm competition and sexual selection. Academic Press, San Diego, pp 503-577

Olsson M, Gullberg A, Tegelström H (1996) Mate guarding in male sand lizards (Lacerta agilis). Behaviour 133:367-386

Pitcher TE, Neff BD, Rodd FH, Rowe L (2003) Multiple mating and sequential mate choice in guppies: females trade up. Proc R Soc Lond B 270:1623-1629

Quinn GP, Keough MJ (2002) Experimental design and data analysis for biologists. Cambridge University Press, Cambridge

Qvarnström A (2001) Context-dependent genetic benefits from mate choice. Trends Ecol Evol 16:5-7

Reusch TBH, Häberli MA, Aeschlimann PB, Milinski M (2001) Female sticklebacks count alleles in a strategy of sexual selection explaining MHC polymorphism. Nature 414:300-302

Richard M, Lecomte J, de Fraipont M, Clobert J (2005) Age-specific mating strategies and reproductive senescence. Mol Ecol 14:3147-3155

Richard M, Losdat S, Lecomte J, de Fraipont M, Clobert J (2009) Optimal level of inbreeding in the common lizard. Proc R Soc Lond B 276:2779-2786

Santos X, Llorente GA (2001) Seasonal variation in reproductive traits of the oviparous water snake, Natrix maura, in the Ebro Delta of northeastern Spain. J Herpetol 35:653-660

Siegel S, Castellan NJ (1988) Nonparametric statistics for the behavioral sciences. McGraw-Hill, New York

Thornhill R, Alcock J (1983) The evolution of insect mating systems. Harvard University Press, Cambridge

Tokarz RR (1998) Mating pattern in the lizard Anolis sagrei: implications for mate choice and sperm competition. Herpetologica 54:388-394

Tregenza T, Wedell N (2000) Genetic compatibility, mate choice and patterns of parentage: invited review. Mol Ecol 9:1013-1027

Van Wyk JH (1995) The male reproductive cycle of the lizard, Cordylus giganteus (Sauria: Cordylidae). J Herpetol 29:522-535

Wong BBM, Candolin U (2005) How is female mate choice affected by male competition? Biol Rev 80:559-571

Zahavi A (1975) Mate selection-a selection for a handicap. J Theor Biol 53:205-214

Zeh JA, Zeh DW (1996) The evolution of polyandry. I. Intragenomic conflict and genetic incompatibility. Proc R Soc Lond B 263:1711-1717 